\title{
Endoparasites of lizards (Lacertilia) from captive breeding and trade networks
}

\author{
A. OKULEWICZ¹ ${ }^{1}$ M. KAŹMIERCZAK² ${ }^{2}$ J. HILDEBRAND¹, M. ADAMCZYK¹
}

1Department of Parasitology, Institute of Genetics and Microbiology, Wrocław University, Przybyszewskiego 63/77, 51-148 Wrocław, Poland, E-mail: anna.okulewicz@microb.uni.wroc.pl; 2Department of Vertebrate Evolutionary Biology and Conservation, Institute of Environmental Biology, Wrocław University, Sienkiewicza 21, 50-335 Wrocław, Poland

\section{Article info}

Received July 2, 2014

Accepted October 23, 2014

\section{Summary}

Parasitic infections are widespread among exotic lizards and cause serious problems in both private captive breeding and trade networks. Among 168 lizards obtained from captive breeding (Zoological Garden in Wrocław and private owners) and trade (pet shops and wholesale) the total prevalence of endoparasites was $42.35 \%$. We detected species of Protozoa, Cestoda, Trematoda - Digenea and Nematoda as well as pseudoparasites. The prevalence of endoparasites was higher in the reptiles obtained from captive breeding $(59.5 \%)$ than in those from trade network, however the parasite species spectrum was wider in the animals form pet shops and wholesales.

Keywords: exotic lizards; endoparasites; helminths: Cestoda, Trematoda - Digenea, Nematoda; Protozoa

\section{Introduction}

According to literature information the level of helminth infection among lizards in the wild can be very high. Studies on house lizards (Gekkonidae): Cosymbothus platyurus and Hemidactylus frenatus from Thailand revealed infection levels of $94.4 \%$ and $100 \%$, respectively. The nematode Pharyngodon sp. (Oxyuridae) was the most prevalent and abundant parasite $(83.3 \%)$ in both lizard species (Saehoong \& Wonqsawad, 1997). The prevalence of parasites in the African lizard Agama agama from Lagos (Nigeria) was $97.6 \%$ in females and $94.1 \%$ in males. Two species of nematodes dominated among the helminths of Agama agama; the prevalence of Strongyluris brevicaudata was $82.3 \%$ and of Parapharyngodon awokoyai - 74.5 \% (Adeoye \& Ogunbanwo, 2007). Likewise, high levels of parasitic infections were reported for exotic reptiles imported into European countries for breeding, for example Rataj et al. (2011) found 18 parasite taxa (mostly nematodes -8 and protozoans -6 ) in 331 specimens of lizards imported into Slovenia, with the prevalence of $76.1 \%$.

About $90 \%$ of wild-caught reptiles die in the first year of captivity because of physical trauma prior to purchasing or because their owners cannot meet their complex dietary and habitat needs (Rataj et al., 2011). Perhaps parasites also contribute to their death.

Table 1. Species, number of specimens and origin of the examined lizards

\begin{tabular}{|c|c|c|c|c|c|c|}
\hline No. & $\begin{array}{c}\text { Scientific Name } \\
\text { Common Name }\end{array}$ & Zoo & Private owner & Wholesale & $\begin{array}{l}\text { Pet } \\
\text { shop }\end{array}$ & Total \\
\hline & AGAMIDAE & & & & & \\
\hline 1. & $\begin{array}{l}\text { Acanthosaura capra } \\
\text { Green Pricklenape }\end{array}$ & 1 & & & & 1 \\
\hline 2. & $\begin{array}{l}\text { Agama agama } \\
\text { Common Agama }\end{array}$ & 2 & & & & 2 \\
\hline 3. & $\begin{array}{l}\text { Gonocephalus chamaeleontius } \\
\text { Chamaeleon Anglehead Lizard }\end{array}$ & & & 7 & & 7 \\
\hline 4. & $\begin{array}{l}\text { Physignathus cocincinus } \\
\text { Chinese Water Dragon }\end{array}$ & 1 & & 47 & 1 & 49 \\
\hline 5. & $\begin{array}{l}\text { Pogona vitticeps } \\
\text { Bearded Dragon }\end{array}$ & 1 & & 2 & 2 & 5 \\
\hline
\end{tabular}




\begin{tabular}{|c|c|c|c|c|c|c|}
\hline No. & $\begin{array}{l}\text { Scientific Name } \\
\text { Common Name } \\
\text { CARPHODACTYLIDAE }\end{array}$ & Zoo & Private owner & Wholesale & $\begin{array}{l}\text { Pet } \\
\text { shop }\end{array}$ & Total \\
\hline 6. & $\begin{array}{l}\text { Underwoodisaurus milii } \\
\text { Thicktailed Gecko } \\
\text { CHAMAELEONIDAE }\end{array}$ & & 1 & & & 1 \\
\hline 7. & $\begin{array}{l}\text { Chamaeleo calyptratus } \\
\text { Veiled Chameleon }\end{array}$ & 2 & 5 & & 3 & 10 \\
\hline 8. & $\begin{array}{l}\text { Trioceros melleri } \\
\text { Meller`s Chameleon }\end{array}$ & 1 & & & & 1 \\
\hline 9. & $\begin{array}{l}\text { Trioceros quadricornis } \\
\text { Four-horned Chameleon }\end{array}$ & & & & 1 & 1 \\
\hline 10. & $\begin{array}{l}\text { Furcifer pardalis } \\
\text { Panther Chameleon } \\
\text { CORYTOPHANIDAE }\end{array}$ & 1 & & & & 1 \\
\hline 11. & $\begin{array}{l}\text { Basiliscus vittatus } \\
\text { Brown Basilisk } \\
\text { GEKKONIDAE }\end{array}$ & 1 & & & & 1 \\
\hline 12. & $\begin{array}{l}\text { Eublepharis macularius } \\
\text { Common Leopard Gecko }\end{array}$ & 1 & 1 & & 2 & 4 \\
\hline 13. & $\begin{array}{l}\text { Gekko gecko } \\
\text { Tokay Gecko }\end{array}$ & & & 1 & & 1 \\
\hline 14. & $\begin{array}{l}\text { Gekko vittatus } \\
\text { Lined Gecko }\end{array}$ & & & 4 & & 4 \\
\hline 15. & $\begin{array}{l}\text { Phelsuma madagascariensis } \\
\text { Madagascar Day Gecko } \\
\text { GERRHOAURIDAE }\end{array}$ & & & & 1 & 1 \\
\hline 16. & $\begin{array}{l}\text { Gerrhosaurus major } \\
\text { Sudan Plated Lizard }\end{array}$ & 1 & & & 2 & 3 \\
\hline 17. & $\begin{array}{l}\text { Gerrhosaurus nigrolineatus } \\
\text { Black-lined Plated Lizard } \\
\text { IGUANIDAE }\end{array}$ & 1 & & & & 1 \\
\hline 18. & $\begin{array}{l}\text { Celestus warreni } \\
\text { Giant Haitian Galliwasp }\end{array}$ & 3 & & & & 3 \\
\hline 19. & $\begin{array}{l}\text { Cyclura cornuta } \\
\text { Rhinoceros Iguana }\end{array}$ & 2 & & & & 2 \\
\hline 20. & $\begin{array}{l}\text { Cyclura nubila } \\
\text { Cuban Rock Iguana }\end{array}$ & 2 & & & & 2 \\
\hline 21. & $\begin{array}{l}\text { Iguana iguana } \\
\text { Green Iguana }\end{array}$ & 1 & & 43 & & 44 \\
\hline 22. & $\begin{array}{l}\text { Sauromalus ater } \\
\text { Northern Chuckwalla } \\
\text { LACERTIDAE }\end{array}$ & 1 & & & & 1 \\
\hline 23. & $\begin{array}{l}\text { Gallotia galloti } \\
\text { Gallot's Lizard }\end{array}$ & 2 & & & & 2 \\
\hline 24. & $\begin{array}{l}\text { Timon lepidus } \\
\text { Ocellated Lizard }\end{array}$ & 1 & & & & 1 \\
\hline 25. & $\begin{array}{l}\text { Lacerta viridis } \\
\text { European Green Lizard } \\
\text { PHRYNOSOMATIDAE }\end{array}$ & 1 & & & & 1 \\
\hline 26. & $\begin{array}{l}\text { Sceloporus serrifer } \\
\text { Blue Spiny Lizard }\end{array}$ & 1 & & & & 1 \\
\hline 27. & $\begin{array}{l}\text { Sceloporus malachiticus } \\
\text { Green Spiny Lizard } \\
\text { POLYCHROTIDAE }\end{array}$ & & & & 1 & 1 \\
\hline 28. & $\begin{array}{l}\text { Anolis equestris } \\
\text { Knight Anole } \\
\text { SCINCIDAE }\end{array}$ & 1 & & 2 & & 3 \\
\hline 29. & $\begin{array}{l}\text { Eumeces schneideri } \\
\text { Schneider's Skink }\end{array}$ & 1 & & 3 & & 4 \\
\hline 30. & $\begin{array}{l}\text { Scincus scincus } \\
\text { Sandfish skink }\end{array}$ & & & 3 & & 3 \\
\hline
\end{tabular}




\begin{tabular}{|c|c|c|c|c|c|c|}
\hline No. & $\begin{array}{l}\text { Scientific Name } \\
\text { Common Name } \\
\text { VARANIDAE }\end{array}$ & Zoo & Private owner & Wholesale & $\begin{array}{l}\text { Pet } \\
\text { shop }\end{array}$ & Total \\
\hline 31. & $\begin{array}{l}\text { Varanus exanthematicus } \\
\text { Savannah Monitor }\end{array}$ & 1 & & 1 & & 2 \\
\hline 32. & $\begin{array}{l}\text { Varanus mertensi } \\
\text { Mertens's Water Monitor }\end{array}$ & 1 & & & & 1 \\
\hline 33. & $\begin{array}{l}\text { Varanus niloticus } \\
\text { Nile Monitor }\end{array}$ & 1 & & & & 1 \\
\hline 34. & $\begin{array}{l}\text { Varanus ornatus } \\
\text { Ornate Monitor }\end{array}$ & 1 & & & & 1 \\
\hline 35. & $\begin{array}{l}\text { Varanus salvadorii } \\
\text { Crocodile Monitor }\end{array}$ & 2 & & & & 2 \\
\hline & TOTAL & 35 & 7 & 113 & 13 & 168 \\
\hline
\end{tabular}

\section{Material and Methods}

The total of 168 lizards representing 35 species and 11 families were examined. Forty-two of them came from captive breeding (35 from City Zoological Garden in Wrocław, 7 from private owners) and 126 specimens from trade networks (113 from wholesale, 13 from pet shops). The specimens obtained from wholesalers (113 animals of 10 species) were especially important, since probably some of them had been captured in the wild (Table 1).

Standard coproscopic methods: direct smear, flotation technique, sedimentation technique were used to detect parasite infections in 168 animals from the zoological garden (35), pet shops (13), private owners (7) and wholesale (113). Protozoans were identified by sodium-acetate acetic acid formaldehyde (SAF) method and modified Ziehl-Neelsen staining. Additionally, necropsy was performed on the dead lizards (105) recived from wholesale.

\section{Results}

Out of the 168 examined specimens, 71 were infected. Infections were detected in 25 captive-bred individuals (prevalence $59.5 \%$ ) and in 46 specimens from trade network (36.5\%). The highest prevalence was recorded for the pet shop animals (13 examined and 8 infected individuals; $61.5 \%$ ) and for those captive-bred in

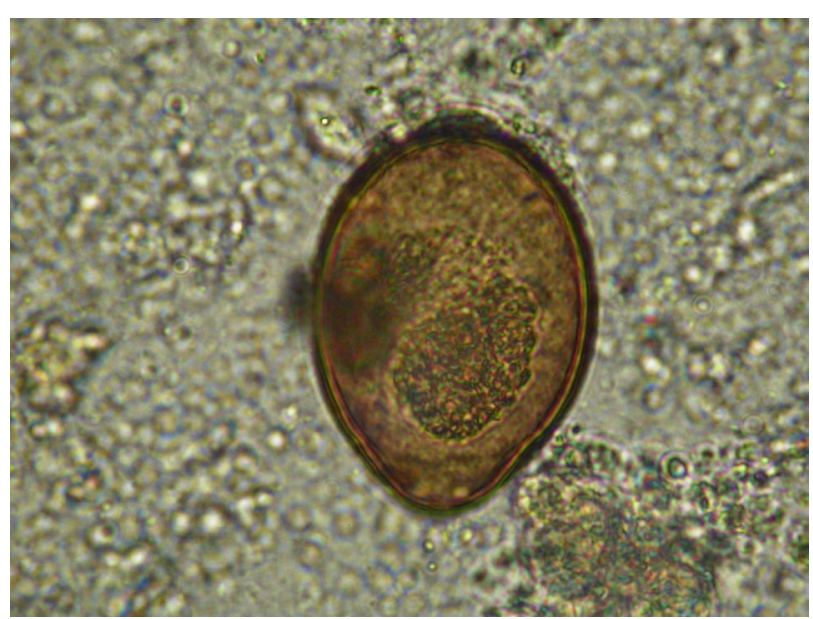

Fig. 1. Nyctotherus sp. the zoological garden (35 examined, 21 infected; $60.0 \%$ ). The sample from private owners was the smallest (7 examined, 4 infected), however the prevalence was rather high, i.e. $57.1 \%$. The smallest prevalence (33.6\%) was observed among the lizards derived from wholesale, where among 113 specimens 38 harboured at least one species of parasites. Table 2 summarizes the number of infected hosts and the of parasite infection in the examined host species.

\section{Protozoa}

Protozoans were detected in faeces of 11 individuals (6.5\%) representing the families Agamidae, Chamaeleonidae, Gekkonidae, Scincidae and Varanidae, from both captive breeding and trade network. The parasites included coccidia of the genera Isospora and Eimeria, as well as representatives of Ciliophora: Nyctotherus sp. and Balantidium sp. (Table 2; Fig. 1).

\section{Digenea}

One digenean species was found in the autopsied Chinese Water Dragon. Mature trematodes of the family Plagiorchiidae were detected in five specimens of Physignathus cocincinus from wholesale. The intensity of infection was $3-5$. The general morphological and morphometric features of these specimens corresponded with the descriptions presented by Sharpilo (1976), Roca and Navarro (1983) and Lewin (1992) Metaplagiorchis molini from Lacerta sp. The measurements (given in micrometers) of Metaplagiorchis molini $(n=19)$ from our own material were the following: body length 2050 - 3675; body width 450 - 1025; diameter of oral sucker $200-375 \times 225-350$; diameter of ventral sucker 170 - 250; cirrus sac length 420 - 570; anterior testis 250 - 325 x 225 - 325; posterior testis $200-375 \times 225-325$; ovary $125-200 \times 125-200$; eggs $30-33 \times 17-20$. M. molini had not been reported previously in exotic lizards. (Fig. 2). Additionally, the analysis faecal samples of one Thicktailed Gecko Underwoodisaurus milii from a private owner revealed indeterminate trematode eggs with a characteristic operculum and $80 \mathrm{x}$ $55 \mu \mathrm{m}$ in size.

\section{Cestoda}

Eggs of a tapeworm of the genus Oochoristica (Anoplocephalidae) were found in faecal samples of two Green Iguana Iguana iguana from wholesale. The average size of the eggs was $55 \mathrm{x}$ $35 \mu \mathrm{m}$ and the hooks of the oncosphere were $15 \mu \mathrm{m}$ long. 
Table 2. Prevalence of endoparasites infecting lizards

\begin{tabular}{|c|c|c|}
\hline $\begin{array}{c}\text { Parasite } \\
\text { (number and percentage of infected hosts) }\end{array}$ & $\begin{array}{c}\text { Host species } \\
\text { (number of examined individuals) }\end{array}$ & $\begin{array}{c}\text { Number of } \\
\text { infected hosts }\end{array}$ \\
\hline \multicolumn{3}{|l|}{ PROTOZOA } \\
\hline Eimeria sp. $(1 ; 0.6 \%)$ & Gekko vittatus (4) & 1 \\
\hline \multirow[t]{2}{*}{ Isospora sp. (3; 1.8\%) } & Chamaeleo calyptratus (10) & 2 \\
\hline & Pogona vitticeps (5) & 1 \\
\hline \multirow{3}{*}{ Nyctotherus sp. $(5 ; 3.0 \%)$} & Chamaeleo calyptratus (10) & 2 \\
\hline & Eumeces schneideri (4) & 1 \\
\hline & Varanus exanthematicus (2) & 2 \\
\hline Balantidium sp. $(2 ; 1.2 \%)$ & Iguana iguana (44) & 2 \\
\hline \multicolumn{3}{|l|}{ DIGENEA } \\
\hline Metaplagiorchis molini (5; 3.0\%) & Physignathus cocincinus (49) & 5 \\
\hline Digenea spp. $(1 ; 0.6 \%)$ & Underwoodisaurus milii (1) & 1 \\
\hline \multicolumn{3}{|l|}{ CESTODA } \\
\hline Oochoristica sp. $(2 ; 1.2 \%)$ & Iguana iguana (44) & 2 \\
\hline \multicolumn{3}{|l|}{ NEMATODA } \\
\hline Enoplida & Acanthosaura capra (1) & 1 \\
\hline \multirow[t]{2}{*}{ Capillaria sp. $(3 ; 1.8 \%)$} & Chamaeleo calyptratus (10) & 1 \\
\hline & Varanus ornatus (1) & 1 \\
\hline \multicolumn{3}{|l|}{ Raillietascaris varani $(13 ; 7.7 \%)$} \\
\hline & Physignathus cocincinus (49) & 13 \\
\hline \multirow[t]{2}{*}{ Meteterakis cophotis $(9 ; 5.4 \%)$} & Physignathus cocincinus (49) & 5 \\
\hline & Gonocephalus chamaeleontius (7) & 4 \\
\hline Strongyluris sp. $(1 ; 0.6 \%)$ & Agama agama (2) & 1 \\
\hline Ascarididae $(1 ; 0.6 \%)$ & Gonocephalus chamaeleontius (7) & 1 \\
\hline \multicolumn{3}{|l|}{ Spirurida } \\
\hline Thubunaea pudica $(1 ; 0.6 \%)$ & Scincus scincus (3) & 1 \\
\hline \multicolumn{3}{|l|}{ Strongylida } \\
\hline Oswaldocruzia sp. (1: $0.6 \%$ ) & Gonocephalus chamaeleontius (7) & 1 \\
\hline Oxyurida & Physignathus cocincinus (49) & 2 \\
\hline Parapharyngodon sp. (3; 1.8\%) & Pogona vitticeps (5) & 1 \\
\hline Pharyngodon sp. $(2 ; 1.2 \%)$ & Eumeces schneideri (4) & 2 \\
\hline \multirow[t]{16}{*}{ Pharyngodonidae (26; 15.5\%) } & Agama agama (2) & 1 \\
\hline & Basiliscus vittatus (1) & 1 \\
\hline & Celestus warreni (3) & 1 \\
\hline & Chamaeleo calyptratus (10) & 3 \\
\hline & Cyclura nubila (2) & 2 \\
\hline & Eublepharis macularius (4) & 2 \\
\hline & Eumeces schneideri (4) & 1 \\
\hline & Gallotia galloti (2) & 2 \\
\hline & Gekko gecko (1) & 1 \\
\hline & Gerrhosaurus nigrolineatus (1) & 1 \\
\hline & Iguana iguana (44) & 3 \\
\hline & Lacerta lepida (1) & 1 \\
\hline & Lacerta viridis (1) & 1 \\
\hline & Physignathus cocincinus (49) & 2 \\
\hline & Pogona vitticeps (5) & 3 \\
\hline & Underwoodisaurus milii (1) & 1 \\
\hline \multicolumn{3}{|l|}{ PSEUDOPARASITES } \\
\hline Hymenolepis nana $(1 ; 0.6 \%)$ & Varanus ornatus (1) & 1 \\
\hline \multirow{3}{*}{ Acari eggs $(4 ; 2.4 \%)$} & Varanus exanthematicus (2) & 1 \\
\hline & Varanus mertenseni (1) & 1 \\
\hline & Varanus salvadori (2) & 2 \\
\hline
\end{tabular}

\section{Nematoda}

As could be expected, nematodes were the most prevalent group of helminths detected in this study. Eggs of Capillaria sp. (1.8\%) were found in Green Pricklenape Acanthosaura capra and Ornate Monitor Varanus ornatus kept in the zoo, as well as in one Veiled Chameleon Chamaeleo calyptratus from a private owner.
The most common nematodes were species of Ascaridida, recorded in $24(14.3 \%)$ of the examined lizards. The autopsy of Chinese Water Dragon Physignathus cocincinus (13 specimens from wholesales) revealed medium-sized ascaridoid nematodes in the intestines $(7.7 \%)$, with the intensity of invasion $2-8$ individuals mature and premature. The measurements and morphological 


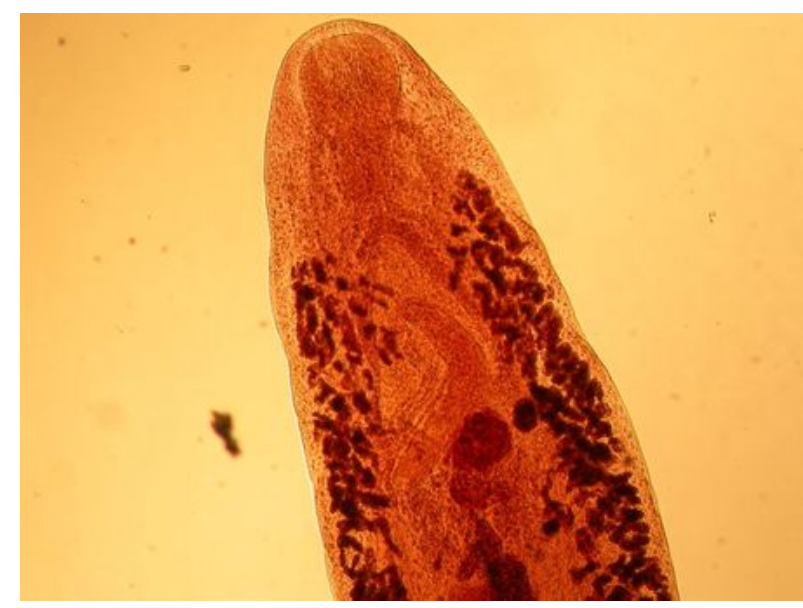

Fig. 2. Metaplagiorchis molini

features suggest that they are Raillietascaris varani, syn. Ophidascaris varani (Sprent 1985) (Fig. 3) a species reported from Varanidae (Varanus monitor, V. swarlli, V. rudicollis, V. nuchalis, V. varius, V. gouldii, V. niloticus) and also Iguana iguanae and Physignathus cocincinus from Thailand, India, Philippine Islands, Africa and Australia. The nematodes showed characteristic morphological features: lips with denticles all around the margins, oral groove present, median lobe absent. The interlabia and cervical alae were present, ventriculus was absent. The intestinal caecum was present. The vulva was situated in the anterior to middle body part. More than 20 precloacal papillae were present; the postcloacal papillae comprised subventrals and subdorsals. The spicules were alate. Measurements (in $\mathrm{mm}$ ): male body length $17.4-29.0$; maximum width $0.21-0.41$; oesophagus length $1.72-3.00$; spicule length 0.75 - 1.20; female body length 42.2 - 61.0; maximum width $0.48-0.87$; oesophagus length $3.63-5.20$; vulva from anterior end $12.5-26.8$.

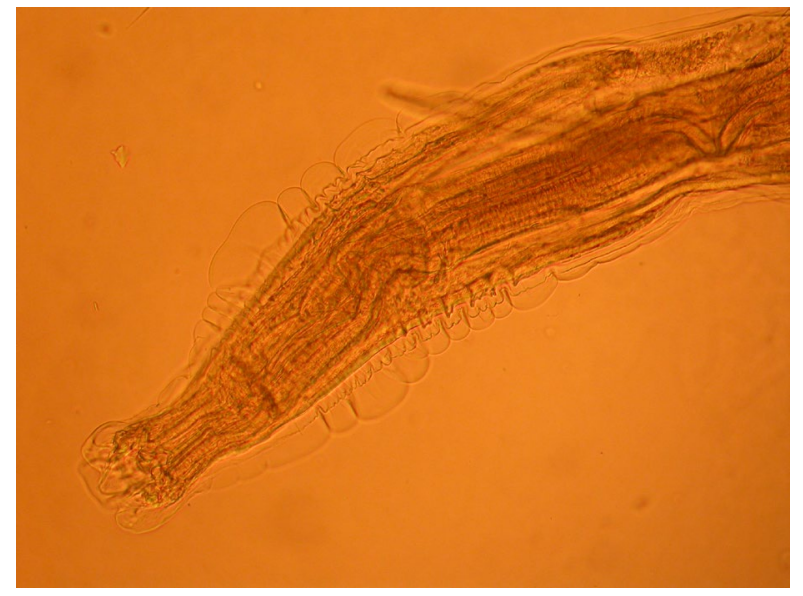

Fig. 3. Raillietascaris varani

The adult worms of Meteterakis cophotis (Heterakidae) were found in five Chinese Water Dragon Physignathus cocincinus and four Javan Humphead Lizard Gonocephalus chamaeleontius originating from wholesale. Both males and females (Table 2, Fig. 4) were located in the large intestine; the intensity of infection was $1-7$ specimens. Nematodes of the genus Meteterakis are common in oriental and Neotropical lizards (Baker, 1984; Zhang \& Zhang, 2011), besides, M. cophotis is regarded as typical of the family Agamidae (Reichenbach-Klinke, 1977).

One ascaridid female, approximately $7 \mathrm{~cm}$ long, was found in the Javan Humphead Lizard Gonocephalus chamaeleontius. Unfortunately, due to its bad condition the identification was impossible.

The analysis of faecal samples revealed a few eggs of Strongyluris sp. $(70 \times 50 \mu \mathrm{m})$ in Common Agama Agama agama from the zoological garden. Based on the presence of characteristic smooth, transparent and thick shell, the eggs were assigned to the genus Strongyluris. According to the literature data, Strogyluris brevicaudata is very common in Agama agama. The prevalence of this nematode in the lizard in Nigeria (Ibaden) was $87.5 \%$ (Omonona et al., 2011).

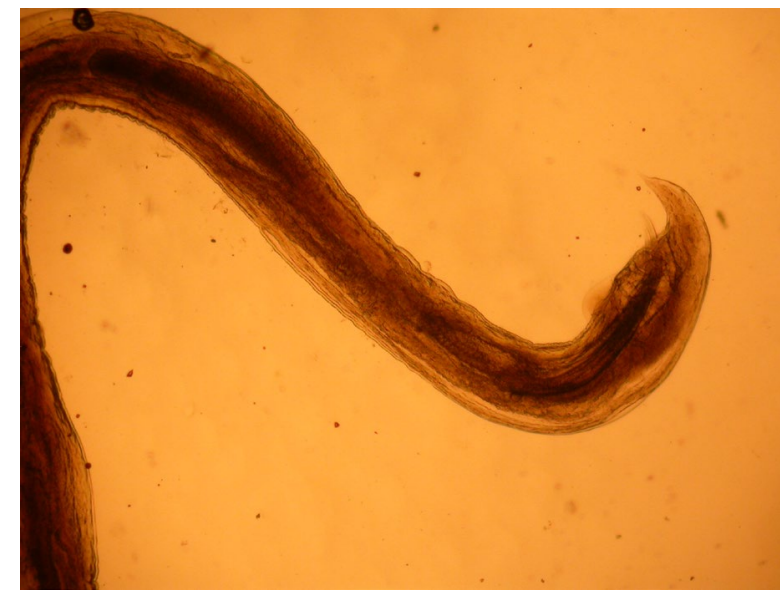

Fig. 4. Metearakis copholis - body end of male

Spirurida (Physalopteridae) were represented by one taxon. Thubunaea pudica was found in the esophagus of one Sandfish Scincus scincus. Moravec et al. (1987) reported T. pudica from many species of lizards in North Africa, including S. scincus. One specimen (female) of Oswaldocruzia sp. (Strongylida) was obtained from the intestine of Javan Humphead Lizard Gonocephalus chamaeleontius. The lack of male specimens made it impossible to identify the species. The genus Oswaldocruzia was reported from a few lizard genera, for example Prionodactylus, Ameiva, Enyalius, from Central and South America (Goldberg \& Bursey, 2004, 2006; Durette-Desset et al., 2006).

Oxyurid nematodes (family Pharyngonidae) were frequent $(18.4 \%)$, especially among the lizards from the zoological garden $(40.0 \%)$ and pet shops $(38.5 \%)$, and less so among those from private owners $(14.3 \%)$ or wholesale $(9.7 \%)$. Using standard coproscopic methods proved to be less effective for detection of oxyurids at the generic level. Necropsy revealed a few females of Pharyngodon sp. (Figs. 5, 6) in the large intestine of two individuals Chinese Water Dragon Ph. Cocincinus, one Bearded Dragon Pogona vitticeps and two Schneider's Skink Eumeces schneideri. Infection with Oxyurida often shows high intensity.

Pseudoparasites - Hymenolepis nana and Acari - should also be mentioned. Their eggs were present in the faecal samples of Varanidae from the zoological garden, which is associated with the diet of these lizards (rodents). Probably these were the eggs of mites of the genus Myobia parasitic of eaten rodents. 


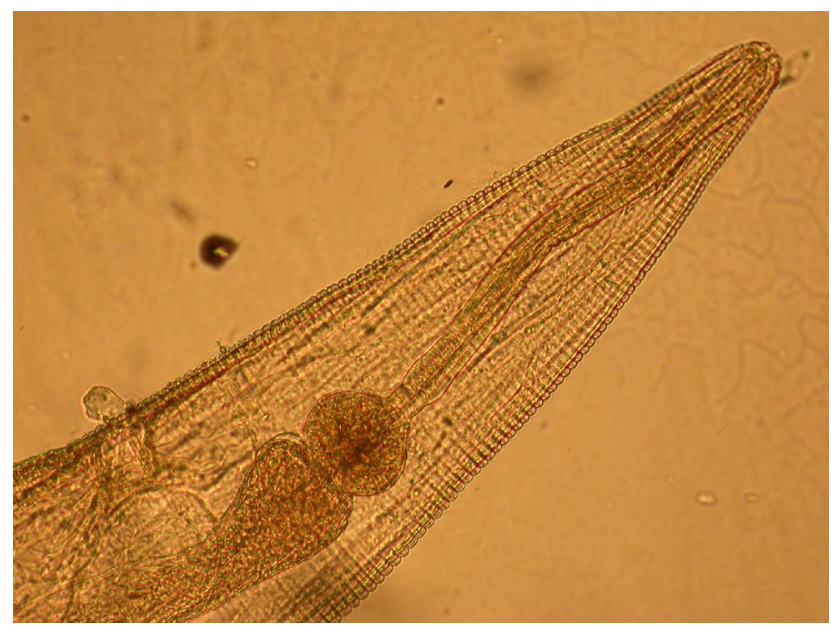

\section{Discussion}

Lizards, especially in the wild, are commonly infected with coccidia. Oocysts of Eimeria sp. were found in $68.7 \%$ of Agama agama from Nigeria (Adeoye \& Ogunbanwo, 2007). Ciliophora, such as Nyctotherus sp., with egg-shaped cysts and an operculum measuring $60 \times 55 \mu \mathrm{m}$ are common, and Balantidium sp. especially in herbivorous lizards and not regarded as pathogens. Rataj et al. (2011) found Nyctotherus sp. in $10 \%$ and Balantidium sp. in $2.4 \%$ of examined animals.

Finding adult Metaplagiorchis molini (Plagiorchiidae) in Chinese Water Dragon $\mathrm{Ph}$. cocincinus is especially noteworthy. M. molini was previously reported from Lacerta sp. and Podarcis muralis (Lacertidae) in Europe, for example France, Germany, Ukraine, Spain and Poland (Lewin, 1992). The origin of the individuals of Chinese Water Dragon (native to East and Southeast Asia) that was examined in this study is not clear. Morphologically our fukes individuals are similar to previously described from Lacertidae, but a molecular characterisation is necessary to confirm this. $A$ probable explanation would be a different species as a direct transfer is not possible due to the need of specific intermediate hosts.

According to some authors, Protocephalidea are more common in lizards than Cyclophyllidea (Gamil, 2012), but in our study only a member of Cyclophyllidea, genus Oochoristica was found. Oochoristica sp. were formerly reported from Iguana iguana, Chamaeleo sp. (Pasmans et al., 2008; Schneller \& Pantchev, 2008) and also from Agamidae: Pogona viticeps and Uromastyx dispar (Rataj et al., 2011).

Nematodes are the most common helminths found in lizards and other reptiles. In this study nematodes were found in $35.7 \%$ of the examined animals. The lizards from the zoological garden and private owners were mostly infected by Pharyngonidae. The reptiles form wholesale showed a large biodiversity of endoparasites, suggesting that those animals were most probably caught in the wild.

Two species of Ascaridida, Meteterakis cophotis and Raillietascaris varani, found in Chinese Water Dragon Ph. cocincinus, seem to be especially interesting. Meteterakis cophotis (Heterakoidea),

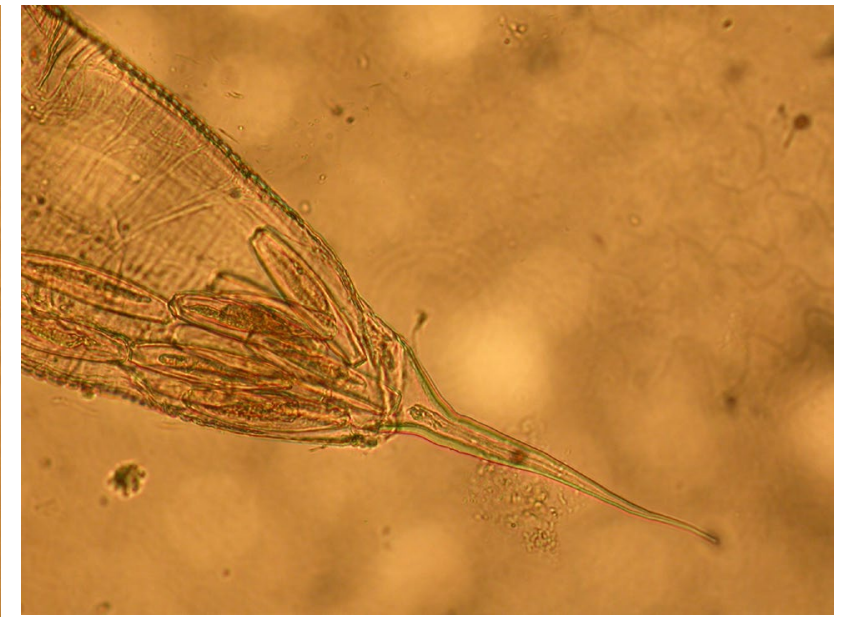

Fig. 6. Pharyngodon sp. -distal part

reported from Agamidae in Sri Lanka, was previously found rather rarely. The morphological features and measurements of the specimens of $M$. cophotis found in this study correspond with the data presented by Skrjabin et al. (1961) and ReichenbachKlinke (1977). Raillietascaris varani, found in Physignathus cocincinus in this study, was usually found in the stomach and intestine, mainly of Varanidae but sometimes also of other lizards, such as Physignathus cocincinus (Agamidae) and Iguana iguana (Iguanidae). This species is typical parasite of stomach and intestine for Varanidae family (Sprent, 1985).

Finding and identifying Meteterakis cophotis and Raillietascaris varani in exotic lizards seems to be valuable, because the presence of unidentified eggs of Ascaridida in faecal samples is often mentioned in the literature (e.g. Rataj et al., 2011).

Oxyuridae are most commonly found in geckos and agamas. Former studies showed high prevalence rates of up to $50 \%$ (Beck \& Pantchev, 2006) or $57.1 \%$ (Rataj et al., 2011). In Varanidae these nematodes were reported quite rarely: Beck and Pantchev (2006) found them only in $4.7 \%$ of the examined lizards. In this study no Oxyuridae were found in Varanidae. Lizards were reported as hosts for more oxyurid species of the family Pharyngonidae (Greiner \& Mader, 2006), but it was impossible to identify those species based only on the measurements and morphological features of eggs. Although recent studies (Wolf et al. 2014) have shown that the use of flotation technique (CNF) allows differentiation of lizard species versus rodent species oxyurid eggs (Aspiculuris/Syphacia, e.g. in monitor lizard). Finding eggs of Capillaria sp. in feaces of Chamaeleo calyptratus (Chamaeleonidae) is pretty unusual. This Veiled Chameleon came from private owner and is very likely that was kept together with some Lacertidae.

The helminth species richness was the highest in Chinese Water Dragon Ph. cocincinus (Agamidae). Helminths were found in 27 $(55.1 \%)$ out of the 49 examined specimens from wholesale and the following species were recorded: one digenean Metaplagiorchis molini (10.2\%) and nematodes: Meteterakis cophotis $(18.4 \%)$, Raillietascaris varani $(26.5 \%)$, Parapharyngodon sp. (4.1\%) and Pharyngodonidae (4.1\%). 


\section{Conclusion}

Lizards originating from captive-breeding (zoological garden and private owners) showed a higher level of infection than those form trade network (pet shops, wholesale), with the prevalence rate of $59.5 \%$ and $36.5 \%$, respectively. The diversity of parasites among the captive-bred lizards was rather low, mostly Oxyuridae and Protozoa were recorded. In the animals from trade network we found the total of 13 species of endoparasites, some of them regarded as rare. We suspect that the high level of parasitic infections may have been the cause of death of some of the lizards from wholesale.

\section{References}

AdeOYE, G.O., OgunBanwo, O.O. (2007): Helminth parasites of the African Lizard Agama agama (Squamata: Agamidae), in Lagos, Nigeria. Rev. Biol. Trop., 55 (2): 417 - 425

BAKER, M.R. (1984): The systematics and zoogeography of Spinicaudinae and Meteterakinae (Heterakoidea: Nematoda) parasitic in reptiles and amphibians. Syst. Parasitol., 6: 275 287. DOI: $10.1007 /$ BF00012206

BeCK, W., PANTCHEV, N. (2006): Praktische Parasitologie bei Heimtieren. Schlütersche Verlagsgesellschaft $\mathrm{mbH}$ \&Co. KG, Hannower: 229 - 293

BURSEY, C.R., GOLDBERG, S.R. (2004): Cosmocerca vrcibradici n. sp. (Ascaridida: Cosmocercidae), Oswaldocruzia vitti n. sp. (Strongylida: Molineoidae), and other helminths from Prionodactylus eigenmanni and Prionodactylus oshaughnessyi (Sauria: Gymnophthalmidae) from Brazil and Ecuador. J. Parasitol., 90: 140 - 145. DOI: $10.1645 / G E-3234$

BURSEY, C.R., GOLDBERG, S.R., VITT, L.V. (2006): New species of Oswaldocruzia (Nematoda: Molineoidae) in Ameiva festiva (Squamata: Teiidae) from Nicaragua. J. Parasitol., 92: 350 - 352. DOI: $10.1645 / G E-3543.1$

Durette-Desset, M.C., Alves Dos Anjos, L., VRCiBradic, D. (2006): Three new species of the genus Oswaldocruzia Travassos, 1917 (Nematoda: Trichostrongylina, Molineoidea) parasites of Enyalius spp. (Iguanidae) from Brazil. Parasite, 13: 115 - 125. DOI: $10.1051 /$ parasite/2006132115

GAMIL, I. (2012): Morphological and molecular studies of Ophiotaenia sp. (Cestoda: Protocephalidea) a parasite of the sandfish lizard Scinus scinus Lineaus, 1758 (Family: Scincidae). World J. Zool., 7 (1): 65 - 74

GIBBONS, L.M. (2010): Keys to the Nematode parasites of Vertebrates. Supplementary Volume, University of London.

GOLDBERG, S.R., BURSEY, C.R. (2001): Intestinal helminths of four species of skinks (Mabuya) (Sauria: Scincinidae) form southern Africa. Onderstepoort J. Vet. Res., 68: 143 - 147

GREINER, E.C., MADER, D.R. (2006): Parasitology. In: MADER, D.R.
(Ed) Reptile Medicine and Surgey. Saunders Elsevier, St. Louis: $343-364$

INGLIS, W.G. (1957): A revision of the superfamily Heterakoidea. Ann. Mag. Natur. Hist., 10 (120): $905-912$

LEWIN, J. (1992): On the validity of Metaplagiorchis molini (Lent et Freitas, 1940) (Trematoda, Plagiorchiidae). Acta Parasitol., 37 (3): $159-161$

MORAVEC, F., BARUŠ, V., RYŠAVÝ, B. (1987): Some parasitic nematodes, excluding Heterakidae and Pharyngonidae, from amphibian and reptiles in Egypt. Folia Parasitol., 34: 255 - 267

OMONONA, A.O., AdEDOKUn, O.A., AdEKOYA-GAFAAR, S.A. (2011): Parasitological studies on agama lizard (Agama agama) in Ibaden. Adv. Environ. Biol., 5 (5): 803 - 807

PASMANS, F., BlahaK, S., MaRTEL, S., PANTCheV, N. (2008): Introducing reptiles into a captive collection: The role of the veterinarian. Vet. J., 175: 53 - 68. DOI: 10.1016/j.tvjl.2006.12.009

RataJ, A.V., Lindtner-Knife, R., Vlachović, K., MaVRI, U., Dovc, A. (2001): Parasites in pet reptiles. Acta Vet. Scand., 53 (33): 1 20. DOI: $10.1186 / 1751-0147-53-33$

REICHENBACH-KLINKE, H.-H. (1977): Krankheiten der Reptilen. VEB Gustav Fisher Verlag Jena. Stuttgart, Germany.

Roca Velasco, V., NavarRo Gomez, P. (1983): Plagiorchis (Metaplagiorchis) molini Lent et Freitas 1940 (Deigenea: Plagiorchodae) parasite de la lagartija roquera, Podacris muralis Laurenti, 1768 (Reptilia: Lacertidae). Rev. Iber. Parasitol., 43 (4): 325 - 332

SAEHOONG, P., WongSAWAD, C. (1997): Helminths in house lizards (Reptilia: Gekkonidae). Suotheast Asian J. Trop. Public Health., 28 Suppl. 1: $184-189$

SchnelleR, P., PantcheV, N. (2008): Parasitology in Snakes, Lizards and Chelonians. Edition Chimaira, Frankfurt am Main.

SHARPILO, V. P. (1976): Parasitic worms of reptiles in the fauna of SSSR. Izd. Naukowa Dumka, Kiev (In Russian)

SKRJABIN, K.I., SHIHOBALOVA, N.P., LAGOdOVSKAJA, E.A. (1961): Basics of nematology. T.X. Oxyurata of animals and humans. $\mathrm{Cz}$. 2. Izd. AN SSR, Moskva. (In Russian)

SPRENT, J.F.A. (1985): Ascaridoid nematodes of amphibians and reptiles: Raillietascaris n.g. Ann. Parasitol. Hum. Comp., 60: 601 $-611$

Velasco, R.V., GomeZ, N. P. (1983): Plagiorchis (Metaplagiorchis) molini lent et freitas 1940 (Digenea: Plagiorchidae) parasito de la lagartija roquera, Podarcis muralis Laurenti, 1768 (Reptilia: Lacertidae). Rev. Iber. Parasitol., 43(4): 325 - 332

Wolf, D., Globokar-VRhovec, M., Failing, K., Rossier, CH., Hermosilla, C., PANTCHEV, N. (2014): Diagnosis of gastrointestinal parasites in reptiles: comparison of two coprological methods. Acta Vet. Scand., 56 (1): 1 - 13. DOI: 10.1186/s13028-014-0044-4

ZHANG, S., ZHANG, L. (2011): A new species of Meteterakis Karve, 1930 (Nematoda: Heterakoidea) from Indotestudo elongata (Blyth) in China with a key to the species of Meteterakis. Zootaxa, 2869: $63-68$ 